\title{
A system of synthetic indicators for the diagnosis of regulated tourist areas of the Valencian coast
}

\author{
R. Temes \\ Department of Urban Design and Regional Planning, \\ Polytechnic University of Valencia, Spain
}

\begin{abstract}
This paper is a partial result of the Research Project 'Strategies for sustainable regeneration in tourism settlements on the Mediterranean Coast (ERAM)' (ref. BIA2011-28297-C02-01) Spain National Plan of Research, 2011. The line of work presented aims at assessing the potential for regeneration of the tourist settlement of the Valencian coast. For this purpose, the methodology employed is the multiple-criteria decision analysis (MCDA) divided into 4 levels: economic dynamics of coastal towns, quality of facilities offering tourist settlements, quality and maintenance of buildings of tourist areas, and impact and vulnerability of the tourist areas on the environment. The research is carried out with a territorial perspective focused on the 68 coastal towns of the Valencian Community (CV) where more than $12.5 \%$ of the GDP is achieved. This research developed a set of indicators such as the 'synthetic index of diversity and tourism resources', 'synthetic index of hotel quality', and others that are shown as partial conclusions of the high regeneration potential in the tourist towns, especially in the province of Castellón. One of the principal database used in the research has been 'Winsitur', the Tourist Information System of the CV (2011). Research shows, on the one hand, that the regeneration of the coastal touristic settlements of the $\mathrm{CV}$ is an opportunity to maintain a high economic activity that tourism brings to this community and, secondly, to make it compatible with the environmental conditions.

Keywords: sustainable regeneration, developed touristic destinations, touristic indicators, touristic diagnosis, Valencian community.
\end{abstract}




\section{Introduction}

Tourism is a highly strategic activity for Valencia, generating more than $12.5 \%$ of GDP and over 13\% of employment. It is, along with agriculture, the economic sector that produces the greatest impact on the territory, so that the set of strategies and actions proposed should include the reception capacity of the territory as a conditioning factor. The current adverse economic circumstances also affect tourism and they have caused a sustained decline in investment in the sector since 2008 as reflected in EXCELTUR [1]. At the same time a redefinition of the different tourism models are being produced globally. Their impacts are still difficult to appreciate, but they will surely require a high quality of the natural environments as well as facilities and services.

In turn, other Spanish regions, as the Balearic Islands or the Canary Islands share lead with the Mediterranean coast regarding tourism in the country. They began some years ago, to take action and propose strategies to reduce dysfunctions beginning to be shown by the tourism industry. Overcrowd leisure destinations with a poor complementary offer, residual public spaces and obsoletes hotels in many cases, have prompted the development of laws like the Law $8 / 2012$, dated July $19^{\text {th }}$ about tourism in the Balearic Islands or the Law $2 / 2013$, dated May $29^{\text {th }}$, for renewal and modernization of Canary Islands' tourism. Both are uneasy about seeking the right framework and the necessary incentives for the renewal of the touristic destinations. Looking at this situation, the main challenge of the Valencian Community, as contained in Spatial Development of the Valencian Community (ETCV) [2], is the definition of a strategy of progressive differentiation of tourism offers, based on the territory as the argument and the support of the tourism model, by renewing and strengthening current destinations and the tourist development of natural and cultural Valencian heritage.

\subsection{General objectives and structure of the work}

In the project named 'Strategies for sustainable regeneration in tourism settlements on the Mediterranean Coast (ERAM)' (ref. BIA 2011-28297-C0201) was established as one of its main objectives, to achieve a representative diagnosis of the 'reality' of the touristic settlements from the Valencian coast. That 'reality' should cover at least the 4 dimensions that have emerged from the main challenge that has the Valencian Community for the future of the tourism industry. These dimensions can be listed as:

1. ECONOMIC DYNAMICS: Economic behavior of tourism in coastal towns.

2. COMPLEMENTARY OFFER: Quality of complementary offer to tourist settlements.

3. BUILDING STOCK: Quality and maintenance of the whole buildings with touristic destination.

4. ENVIRONMENT: Impact and vulnerability of tourist settlements on the environment. 
This paper aims to expose, in a summarized manner, the steps taken to determine the tourist coastal areas that show greater dysfunctions, and offer a number of future strategies for the sustainable regeneration of settlements. For this, the article is divided into four parts. In first place are defined the synthetic variables and indicators used to represent each of the dimensions considered in the analysis. Then it is used for gathering the cases the multivariable statistics of conglomerate of the $\mathrm{k}$ averages (cluster analysis) technique. Next it develops a multi-criteria analysis using the technique of linear weighted summation, to determine the suitability for the territorial development of the touristic settlements. Finally we use graphical procedures of selection using GIS overlay which framed the problematic areas. We conclude by providing some ideas about the results and also we suggest some policies to try to reverse the problems detected. The methodology applied in this work is quantitative, with the use of secondary sources and SPSS software for the statistical treatment and ArcGIS for the creation of maps.

\section{Territorial and chronological frame of reference}

The distribution of tourism demand in the Valencian Community highlights that, despite the various diversifying trends of recent times, the Valencian tourist system - from a territorial perspective - lies essentially in the conurbation of the littoral structured by large infrastructures such as CN-340, AP-7 from 'Vinaròs' to Valencia and the $\mathrm{CN}-332$ between the regional capital and 'Pilar de la Horadada', that have acted as the main catalysts of the urbanization process. The coast length of the Valencian Community is about $470 \mathrm{~km}$, of which more than $75 \%$ are low sandy coast, being the rest high coast or cliffs. However, the presence of major touristic destinations in the pre-coastal and the interior is growing. This research has focused mainly on tourism pre-coastal and coastal, covering 68 municipalities that represent $15 \%$ of the surface of the Community and are home to a population of more than 2.8 million people on a permanent basis, which is increased several times with the arrive of more than 20 million tourists who visit the Valencian Community each year. Likewise, this research focuses on regulated touristic areas instead of on the residential tourist spaces, being aware of their importance and weight in this region as well (Menero and Pitarch [3].)

The chronological frame is going to be directly related to the nature of secondary sources used for the manufacture of synthetic indices needed for the research. The 4 main sources for this work have been:

- Winsitur. Tourist Information System of the Valencian Community (data 2011), is the most complete tourist information node of the Community that includes information about tourist accommodations, complementary offer, services and resources. The elaboration of the same depends on the 'Consellería of Tourism'.

- Economic Yearbook of Spain (La Caixa, 2012), collects statistics of economic, commercial and demographic indicators, on a municipal, provincial and regional level. The Center Gauss of the Institute Lawrence R. 
Klein, of the Autonomous University of Madrid is responsible for its realization.

- Survey of hotel occupancy, (National Institute of Statistic, INE, 2012), gathers all the properties that are registered as such in the corresponding register of the tourism departments of each Autonomous Community and analyzes the total number of incoming travelers, overnight stays, level of occupancy, average length of stay, etc... The organism responsible for its realization is the INE.

- Information System on Occupation of the Soil of Spain (SIOSE) (National Geographic Institute, IGN, 2011), whose objective is to integrate the information from Data Bases about coverage and land uses of the Autonomous Communities and the General Administration of the State. The SIOSE consists of an alphanumeric basis represented by polygons that show the spatial unit of the terrain in which soil occupation appears with homogeneous or different coverage between themselves.

Part of the mentioned statistical information has been georeferencing through the software BatchGeo to determine its necessary space position in the analysis.

\section{Determination of the basic variables of the study: definition of indicators}

Once identified the dimensions that define the ETCV, the indicators of these dimensions described should be selected. Obviously, having to choose a number of indicators, we lose shade of the concept, but we gain the possibility of measure them. The selection process of variables and transformation of them into simple and complex indicators, supposed a fundamental phase of the analysis and was carried out through participation of the Working Group of the Project Research ERAM. In the discipline there is no consensus on the determination of the variables that allow us to diagnose the situation of the tourist destinations. In our case, we have taken reference from the works of Soares et al. [4] in which it is done a review of studies to delimit the main indicators in the analysis of the life cycle of tourism destinations.

In our case the indicators and variables derived are summarized in Table 1.

\section{Synthesis of indicators: hierarchical cluster analysis and $K$ averages}

For the purposes of classification or grouping of municipalities with similar behavior referred to the indicators exposed before, it have been used an analysis of conglomerate (cluster analysis) method. This method makes it possible to classify into two or more groups the tourist towns of the sample set, based on the similarity to a set of specified characteristics. Although there are two different techniques, the hierarchical cluster analysis and the analysis of the averages $\mathrm{K}$ in cluster analysis, we will use a procedure that involves the use of both techniques. 
Table 1: Variables and indicator.

\begin{tabular}{|c|c|c|c|}
\hline & Variable & Source & Indicator \\
\hline \multicolumn{4}{|c|}{ ECONOMIC DYNAMICS } \\
\hline - & $\begin{array}{l}\text { Economic activities tax } \\
\text { corresponding to the tourist } \\
\text { activities }\end{array}$ & $\begin{array}{l}\text { Economic Yearbook of Spain } \\
\text { (La Caixa, 2012) }\end{array}$ & $\begin{array}{l}\text { Synthetic indicator of } \\
\text { tourism }\end{array}$ \\
\hline - & Average hotel occupancy & $\begin{array}{l}\text { Survey of hotel occupancy, } \\
\text { (INE, 2012) }\end{array}$ & $\begin{array}{l}\text { Trend indicator of the } \\
\text { dynamics of hotel occupancy }\end{array}$ \\
\hline- & $\begin{array}{l}\text { Total overnight stays in } \\
\text { hotel establishments }\end{array}$ & $\begin{array}{l}\text { Survey of hotel occupancy, } \\
\text { (INE, 2012) }\end{array}$ & $\begin{array}{l}\text { Indicator of the dynamics of } \\
\text { overnight stays }\end{array}$ \\
\hline \multicolumn{4}{|c|}{ COMPLEMENTARY OFFER } \\
\hline $\begin{array}{l}- \\
- \\
-\end{array}$ & $\begin{array}{l}\text { Monuments } \\
\text { Tourist resources } \\
\text { Leisure and entertainment } \\
\text { Active tourism } \\
\text { Health tourism }\end{array}$ & $\begin{array}{l}\text { Winsitur. Tourist Information } \\
\text { System of the Valencian } \\
\text { Community (data 2011) }\end{array}$ & $\begin{array}{l}\text { Synthetic indicator of } \\
\text { diversity and tourism } \\
\text { resources }\end{array}$ \\
\hline- & $\begin{array}{l}\text { Number of blue flags in } \\
\text { recent years } \\
\text { Quality certifications (flag } \\
\text { Qualitur, iso } 14001 \text {, iso } \\
9001, \text { q icte - une } 187003 \text { ) }\end{array}$ & $\begin{array}{l}\text { Winsitur. Tourist Information } \\
\text { System of the Valencian } \\
\text { Community (data 2011) }\end{array}$ & $\begin{array}{l}\text { Synthetic indicator of quality } \\
\text { of beaches }\end{array}$ \\
\hline- & $\begin{array}{l}\text { Number of blue flags in } \\
\text { recent years } \\
\text { Number of moorings }\end{array}$ & $\begin{array}{l}\text { Winsitur. Tourist Information } \\
\text { System of the Valencian } \\
\text { Community (data 2011) }\end{array}$ & $\begin{array}{l}\text { Synthetic indicator of quality } \\
\text { of marinas }\end{array}$ \\
\hline - & $\begin{array}{l}\text { Number of squares of First } \\
\text { and Great comfort }\end{array}$ & $\begin{array}{l}\text { Winsitur. Tourist Information } \\
\text { System of the Valencian } \\
\text { Community (data 2011) }\end{array}$ & $\begin{array}{l}\text { Synthetic indicator of quality } \\
\text { of establishments of camping }\end{array}$ \\
\hline- & $\begin{array}{l}\text { Number of Golf courses } \\
\text { Area of golf courses }\end{array}$ & $\begin{array}{l}\text { Winsitur. Tourist Information } \\
\text { System of the Valencian } \\
\text { Community (data 2011) }\end{array}$ & $\begin{array}{l}\text { Synthetic indicator of quality } \\
\text { of supply of golf courses }\end{array}$ \\
\hline \multicolumn{4}{|c|}{ BUILDING STOCK } \\
\hline - & Number of hotel beds $>3 *$ & $\begin{array}{l}\text { Winsitur. Tourist Information } \\
\text { System of the Valencian } \\
\text { Community (data 2011) }\end{array}$ & $\begin{array}{l}\text { Synthetic indicator of hotel } \\
\text { quality }\end{array}$ \\
\hline- & $\begin{array}{l}\text { Actual age taking into } \\
\text { account the reforms, if these } \\
\text { have been totals }\end{array}$ & $\begin{array}{l}\text { Winsitur. Tourist Information } \\
\text { System of the Valencian } \\
\text { Community (data 2011) }\end{array}$ & $\begin{array}{l}\text { Synthetic indicator of age of } \\
\text { the constructed hotels }\end{array}$ \\
\hline - & $\begin{array}{l}\text { Number of reforms carried } \\
\text { out in the establishments }\end{array}$ & $\begin{array}{l}\text { Winsitur. Tourist Information } \\
\text { System of the Valencian } \\
\text { Community (data 2011) }\end{array}$ & $\begin{array}{l}\text { Synthetic indicator of } \\
\text { dynamism of the reforms } \\
\text { hotels }\end{array}$ \\
\hline \multicolumn{4}{|c|}{ ENVIRONMENT AND OCCUPANCY OF THE SOIL } \\
\hline- & $\begin{array}{l}\text { Flood risk } \\
\text { Accessibility to water } \\
\text { resources }\end{array}$ & $\begin{array}{l}\text { Consellería d' } \\
\text { Infraesctructures, Territori i } \\
\text { Medi Ambient, } 2012\end{array}$ & $\begin{array}{l}\text { Global capacity of tourist } \\
\text { uses reception }\end{array}$ \\
\hline- & $\begin{array}{l}\text { Aquifer contamination } \\
\text { Natural protection }\end{array}$ & $\begin{array}{l}\text { Consellería d'Infraesctructures, } \\
\text { Territori i Medi Ambient, } 2012\end{array}$ & $\begin{array}{l}\text { Global capacity of tourist } \\
\text { uses reception }\end{array}$ \\
\hline & Artificial coverages. Level 1 & $\begin{array}{l}\text { Information system on } \\
\text { Occupation of the Soil of Spain } \\
\text { (SIOSE) (IGN, 2011) }\end{array}$ & $\begin{array}{l}\text { Occupation of the soil with } \\
\text { building }\end{array}$ \\
\hline
\end{tabular}

Firstly, we apply the hierarchical cluster analysis to determine the number of clusters or groups which are suitable. We also calculate the centroids - average values of the set of variables for each of the groups-corresponding to the chosen 
solution. Then we use the method of the conglomerates of the averages $\mathrm{K}$ by entering the number of clusters that are considered suitable according to the hierarchical cluster analysis. We use the centroids obtained with the previous technique as a starting point, using them as initial centroids from where the clustering of tourist municipalities' process begins.

To start the analysis, we have worked on the dimension 'Complementary offer' and 'Building Stock'. In the first case, we use the 5 indicators listed in Table 2, for the analysis of hierarchical conglomerates. After the study of the dendrogram and its distance matrix, we determine the formation of 2 groups, with no observation points further away from the rest. In the second case, we used the 3 indicators of the 'Building Stock' and after the hierarchic analysis it also goes over to a group of 2 agglomerates

From this phase we proceed with the $\mathrm{k}$ media analysis based on the division in 2 typologies in each case. Referring to the group 'Complementary Offer', it is performed a Cluster 1 with 11 municipalities and a Cluster 2 with 57 municipalities. The Cluster 1 is representative of the municipalities with high quality of beach and camping areas offering. The Cluster 2 represents municipalities which have a low quality range of beaches and accommodation in camping areas. However the representation of the diversity of the complementary offer, the quality of the marinas and the influence of golf courses is similar in the 2 groups.

Table 2: $\quad$ Final cluster centers.

\begin{tabular}{|l|c|c|}
\hline \multirow{2}{*}{} & \multicolumn{2}{|c|}{ Cluster } \\
\cline { 2 - 3 } & 1 & 2 \\
\hline IND_1_Div & 0.123 & 0.086 \\
\hline IND_2_Beach & 0.524 & 0.171 \\
\hline IND_3_Marinas & 0.075 & 0.098 \\
\hline IND_4_Camp & 0.787 & 0.024 \\
\hline IND_5_Golf & 0.667 & 0.534 \\
\hline
\end{tabular}

With respect to the grouping of the 'Building Stock' it is performed a Cluster 1 with 31 municipalities and a Cluster 2 with 37 municipalities. Cluster 1 is representative of the municipalities with a predominance of low class hotels $\left(<3^{*}\right)$, very old and with few reforms. However the 2 Cluster represents the opposite: predominance of hotels of $>3^{*}$ in which there have been reforms and whose average age is significantly lower than that in the previous group. Data is collected in Table 3 . 
Table 3: $\quad$ Final cluster centers.

\begin{tabular}{|l|c|c|}
\hline \multirow{2}{*}{} & \multicolumn{2}{|c|}{ Cluster } \\
\cline { 2 - 3 } & 1 & 2 \\
\hline IND_6_Hotel & 0.012 & 0.852 \\
IND_7_Age & 0.125 & 0.447 \\
\hline IND_8_Ref & 0.183 & 0.307 \\
\hline
\end{tabular}

\section{Calculation of territorial aptitude: multi-criteria assessment using weighted linear summation}

The conduct of studies where the environmental dimension is valued, as it is our case, seek the compatibility of the physical and natural environment with different applications that potentially can be implemented. For this, it is essential to carry out a joint assessment, that will offers us a mapping with the delimitation of the different levels of adaptation of the characteristics of the physical and natural environment, regarding to the uses that we want to assess. The territorial skills analysis is based on the definition of three key concepts:

- Aptitude: Adaptation of the physical environment to the existing urban uses. For the determination of the various levels of adaptation we must obtain before, the different situations of capacity and vulnerability.

- Capacity: The degree of sufficiency of the characteristics of the physical environment necessary for the implementation of different urban uses. We could also define it as how greater or less difficulty can the conditions of the physical environment exercise for the establishment of different urban uses.

- Vulnerability: The degree of deterioration or destruction of the present environmental values generated by different urban uses. Also it could be defined as the environmental impact that could generate the different urban uses.

The object of the present methodology is to establish a basic zoning of the territory to identify areas suitable for the establishment of tourist uses from the point of view of the physical environment, maximizing the capabilities and minimizing the vulnerabilities.

The analysis of territorial aptitude is therefore, a multi-criteria evaluation where is often used an additive technique of the weighted linear summation in which the assessment factors are combined using a weight for each one of them and adding the results according to the following equation:

$$
a_{i}=\sum_{j=1}^{j} w_{j} x_{i j}
$$

where, $a_{i}$ is the ability of the cell $i, w j$ is the weight assigned to the $j$ factor and $x i j$ is the value of the factor $j$ in the cell $i$.

In our case, this is a technique used using instead a weight of 1 of value that standardizes all the variables that are listed in Table 4. It justifies the use of these 
variables as they are the most restrictive for a use of public concurrency implementation point of view as it is the case of the tourist activity.

Table 4: Analysis of territorial aptitude variables.

\begin{tabular}{|c|c|c|}
\hline & Variable & Source \\
\hline \multicolumn{3}{|c|}{ TERRITORIAL CAPACITY } \\
\hline - & Flood risk & $\begin{array}{l}\text { Territorial Action Plan of sectoral character on the } \\
\text { prevention of flood risk in the Valencian } \\
\text { Community (PATRICOVA), } 2003\end{array}$ \\
\hline 一 & Accessibility to water resources & $\begin{array}{l}\text { Potential accessibility to water resources in the } \\
\text { Community of Valencia, } 1998\end{array}$ \\
\hline \multicolumn{3}{|c|}{ TERRITORIAL VULNERABILITY } \\
\hline - & $\begin{array}{l}\text { Vulnerability to contamination of } \\
\text { aquifers }\end{array}$ & $\begin{array}{l}\text { Vulnerability to contamination of groundwater by } \\
\text { urban activities in the Valencian Community, } 1995\end{array}$ \\
\hline- & $\begin{array}{l}\text { Micro-reserves } \\
\text { Natural Park } \\
\text { Sites of community interest }\end{array}$ & $\begin{array}{l}\text { Natural protected areas present on the server } \\
\text { TerraSIT, } 2014\end{array}$ \\
\hline
\end{tabular}

The joint and combined evaluation of the different situations of vulnerability and capacity, give us as a result the double entrance matrix (Table 5) in which will be do the integrated analysis of different situations:

Table 5: Matrix capacity-vulnerability.

\begin{tabular}{|c|c|c|c|c|c|}
\hline & \multicolumn{4}{|c|}{ GLOBAL VULNERABILITY } \\
\hline & & A1 & B1 & C1 & C2 \\
\hline \multirow{3}{*}{$\begin{array}{l}\text { GLOBAL } \\
\text { CAPACITY }\end{array}$} & A1 & SL (1\%) & A (IVA) $(29 \%)$ & \multirow{2}{*}{$\begin{array}{l}\text { DES } \\
(11 \%)\end{array}$} & \multirow{2}{*}{$\begin{array}{l}\text { MDES } \\
(0.1 \%)\end{array}$} \\
\hline & B1 & A (VTE) $(1 \%)$ & $\begin{array}{c}\text { A (IVA and VTE) } \\
(42 \%)\end{array}$ & & \\
\hline & C1 & \multicolumn{4}{|c|}{ NP $(16 \%)$} \\
\hline
\end{tabular}

where:

SL - permitted uses without limitation.

A (VTE) - permitted uses prior favorable report of technical feasibility.

A (IVA) - permitted uses prior favorable report of environmental sustainability.

A (IVA and VTE) - permitted uses prior favorable report of technical feasibility and environmental sustainability.

DES - inadvisable use for incompatibility with a sustainable development.

MDES - very inadvisable use for incompatibility with a sustainable development.

$\mathrm{NP}$ - in general, prohibited uses.

With the data in the matrix we can observe that $27 \%$ of the surface of the coastal municipalities have undesirable or prohibited situations for the development of tourist settlements. However, these figures will be specified 
in the following steps, since they referred to the total of the surface of the coastal municipalities and not exclusively to the part of the tourist establishments situated on the coast. That is the object of our attention.

\section{Graphical procedures of selection 'overlay' using GIS}

The last step of this methodological sequence for the determination of the areas where the worst conditions are concentrated from the 4 dimensions analyzed for official tourist and coastal settlements, goes through 3 chained processes of overlay, with part of the previous results and other new variables needed for research. The scheme that we will follow is as follows:

1. Overlay with the delimitation of Cluster 'Complementary offer' and Cluster 'Quality of the building'. Definition of cases. Selection of municipalities with the worst results.

2. From the previous selection, incorporation of the enclosures corresponding to the 'Artificial coverages' of the SIOSE for pointing exactly the urban developments inside the municipality. Then we use overlay on the two layers of territorial inaptitude soil, 'DES' and 'NP', for delimiting the urban areas developed on soils without aptitude.

3. With the previous result, we use overlay on the indicators of Economic Dynamics, to obtain the tourist areas with a regressive trend.

\subsection{Overlay of the cluster of 'Complementary offer' and 'Building quality'}

Starting from the previous 4 clusters, the next step in the analysis is to perform an overlay of those groups to assess the possible combinations. Initially these combinations are summarized in Table 6:

Table 6: Overlayer of cluster.

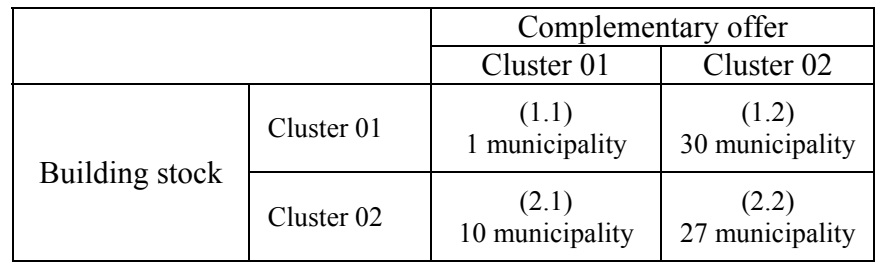

From these combinations, the two most interesting from the point of view of the analysis are the (1.2) and (2.1). The combination (1.2), points to the municipalities where there is both a complementary offering low as a building stock in worst conditions of quality (Deficit Municipalities). On the other hand, the combination (2.1) represents the municipalities where both the complementary offer as the building stock has high levels of quality and satisfaction (Balanced Municipalities). As we can see in Table 6 we have 30 Deficit Municipalities and 10 Balanced Municipalities. There are 28 municipalities in which at least one of the two dimensions is deficient, predominated by the cases of complementary offer problems. 


\subsection{Overlay with the indicators of economic dynamics}

With the previous results, we proceed now to assess the economic dynamics of the previous groups. We will use the synthetic indicator of tourist activity, the trend indicator of the dynamics of hotel occupancy and the indicator of the dynamics of overnight stays listed in table 1. Starting from the superposition of these indicators with the deficit municipalities and balanced municipalities, we get as a result the data in Table 7.

Table 7: Cluster's overlayer.

\begin{tabular}{|l|l|c|c|}
\hline \multicolumn{2}{|c|}{} & \multicolumn{2}{|c|}{ Grouping of municipalities } \\
\cline { 3 - 4 } \multicolumn{2}{|c|}{ Economic indicators } & Deficit Munic. & Balanced Munic. \\
\cline { 2 - 4 } & Regressive Ec. Dynamics & 11 municipalities & 2 municipalities \\
\hline
\end{tabular}

\subsection{Overlay of artificial coverage of the SIOSE with delimitations DES and NP of Territorial Aptitude.}

Finally, with the 17 cases in which the Deficit Municipalities and the regressive economic dynamic occur simultaneously, we value the overlay between the Artificial coverage of the SIOSE and the areas identified as Use inadvisable (DES), Use highly undesirable (MDES) and Use prohibited (NP) and we obtain the results of Table 8 .

Table 8: Artificial costal area affected.

\begin{tabular}{|l|c|c|}
\hline Municipalities & Artificial coastal area affected (ha.) & Province \\
\hline Sueca & 197.23 & Valencia \\
\hline Canet d'en Berenguer & 153.05 & Valencia \\
\hline Tavernes de la Valldigna & 125.60 & Valencia \\
\hline Borriana/Burriana & 117.28 & Castellón \\
\hline Almassora/Almazora & 108.47 & Castellón \\
\hline Nules & 64.59 & Castellón \\
\hline Moncofa & 55.21 & Castellón \\
\hline Almenara & 55.14 & Castellón \\
\hline Els Poblets & 36.17 & Alicante \\
\hline Xilxes/Chilches & 2.77 & Castellón \\
\hline
\end{tabular}

\section{Conclusions}

We can observe that the major concentration of artificial affected coast area appears to be absorbed by two municipalities of Valencia. However it is in Castellón where there is a larger number of municipalities affected in contrast with Alicante, where there is just one of a total of 10. 
As a conclusion to our work we will highlight some ideas:

-The behavior of the touristic municipalities of the Valencian Community is asymmetric among its three provinces, being the most affected one Castellon, followed by Valencia and Alicante.

-This study should be extended with the new Flooding Risk Plan of the Valencian Community (PATRICOVA), which is on public exhibition, as well as with the evaluation of the unofficial hotel offering.

-The method used, with a quantitative bases, can be a point of reference to develop a global evaluation of the Valencian Community territory. Although a qualitative evaluation of the data should also be taken into account.

-This research focuses on regulated touristic areas instead of on the residential tourist spaces, being aware of their importance and weight of them in this Region. It is inevitable to extend this research with an evaluation of the renting offer of apartments or detached houses and summertime apartments (not register neither of them as tourist residences) to have a complete vision of the reality of the Valencian Community due to its importance as the major touristic offers on the coastline areas. The most difficult part of this research is to identify this unregistered tourism offering. A source to solve this situation is to use the "not first residence" registration found on the "Censo de Población y vivienda" (Census of inhabitants and residences).

-Because of the importance on terms of GDP and jobs that the tourism sector has in the Valencian Community and the degree of development of the sector, it is necessary to find some solutions, promoted by the administration, to face this important challenge, following the steps taken by other areas of the country, such as the Canary Islands or the Balearic Islands.

\section{References}

[1] EXCELTUR, Estudio del Impacto económico del turismo sobre la economía y el empleo de la Comunitat Valenciana 2009. IMPACTUR, Generalitat Valenciana, 2010.

[2] Generalitat Valenciana, Estrategia Territorial de la Comunitat Valenciana (ETCV), Conselleria de Infraestructuras, Territorio y Medio Ambiente, 2011.

[3] Menero, E. \& Pitarch, M., El litoral turístico valenciano: intereses y controversias en un territorio tensionado por el residencialismo. Boletín de la Asociación de Geógrafos Españoles, 56, pp. 177-200, 2011.

[4] Soares, J., Gandara, J. \& Baidal, J., Indicadores para analizar la evolución del ciclo de vida de los destinos turísticos litorales. Investigaciones Turísticas, 3, pp.19-38, 2012. 